\title{
Early effects of oil on rat uterine epithelium sensitized for decidual induction
}

\author{
Ö. Lundkvist, I. Ljungkvist and O. Nilsson \\ Reproduction Research Unit, Biomedical Centre, Box 571, S-751 23 Uppsala, Sweden
}

Peanut oil injected into the uterine lumen of the rat or mouse is a well known deciduogenic stimulus (Finn \& Keen, 1963; Finn \& Hinchliffe, 1964, 1965). It is believed to induce a decidual reaction by a mechanism similar to that of the implanting blastocyst (Finn \& Porter, 1975). This view is primarily based on the fact that the hormonal requirements for (Finn, 1965; Meyers, 1970) and the morphological changes of the stroma after (Finn \& Hinchliffe, 1964, 1965) induction are similar to those for blastocyst implantation. Peanut oil has, therefore, often been used to study early decidualization (Hetherington, 1968; Miller, 1973).

However, oil has been shown to cause two types of epithelial cell death, which differ from those seen during normal implantation (Hinchliffe \& El-Shershaby, 1975). First, dead epithelial cells were observed after the appearance of the Pontamine Blue response. Although these cells were morphologically similar to the single dead cells of early implantation (Wilson \& Smith, 1970), their number was comparatively greater. Second, the general breakdown of the antimesometrial epithelium differed from that occurring during late implantation, being more rapid than during normal pregnancy and morphologically different. These differences in morphological response might indicate that oil and blastocyst affect the uterine epithelium differently and that their mechanisms of decidual induction differ. We have therefore extended the studies to cover the earliest effects of oil on the sensitized uterine epithelium.

To permit exact timing of the uterine sensitivity to artificial induction, rats with experimentally delayed implantation were used. Pregnant Sprague-Dawley rats (Anticimex, Stockholm) were bilaterally ovariosalpingectomized on Day 3 of pregnancy, the morning spermatozoa were found in the vaginal smear being designated Day 1 of pregnancy. After the operation all animals received $5 \mathrm{mg}$ progesterone s.c. daily and $0.1 \mu \mathrm{g}$ oestradiol-17 $\beta$ s.c. on Day 8 . At $20 \mathrm{~h}$ after the oestradiol injection, i.e. during the period of maximal uterine sensitivity (De Feo, 1967), 0.05 ml peanut oil was injected into the left uterine horn of 39 rats. A similar amount of sterile saline was given to 11 rats. All injections were performed with a 30-gauge needle connected to an AGLA micrometer syringe (Burroughs Wellcome \& Co., London) and lasted for $60 \mathrm{sec}$. Care was taken not to injure the uterus during the operation.

All animals received $0.3 \mathrm{ml}$ of a $1 \%$ Pontamine Sky Blue solution (6BX) in saline i.v. $15 \mathrm{~min}$ before being killed. Rats given oil were killed at $\frac{1}{2}, 2,4,6,8$ and $24 \mathrm{~h}$ after the injection, while those given saline were killed 4 and $24 \mathrm{~h}$ later. At autopsy the abdominal aorta was perfused for 5 min with $2.5 \%$ glutaraldehyde in phosphate buffer and the uteri were then checked for blue sites. The results are given in Table 1 . When possible, 4 positive and 4 negative sites were excised from the treated horn, while 3 sites (controls) were taken from the untreated horn.

After being dehydrated through a series of graded ethanol, the tissues blocks were embedded in Epon. For light microscopy transverse sections, $1 \mu \mathrm{m}$ thick were cut on an LKB Pyramitome. Sections were cut at every $200 \mu \mathrm{m}$ from each uterine piece and stained in a $1 \%$ alkaline toluidine blue solution. For electron microscopy ultrathin sections were cut on an LKB Ultrotome and stained in uranyl acetate and lead citrate. These sections were examined in a JEOL $300 \mathrm{~B}$ electron microscope.

Induction of the decidual reaction with oil was found to be associated with pronounced changes. By 30 min after the injection of oil, there were numerous condensed epithelial cells and oil droplets in the uterine lumen. The condensed cells were found throughout the whole length of the uterus and mostly antimesometrially. Similar condensed cells were present within the epithelial lining, sometimes representing as much as $5-10 \%$ of the total number of cells (Pl. 1, Fig. 1). They mostly appeared 
Table 1. Induction of the decidual reaction in the rat by intrauterine injection of saline and peanut oil

\begin{tabular}{lccc}
\hline Decidual & $\begin{array}{c}\text { Time after } \\
\text { injection } \\
\text { (h) }\end{array}$ & $\begin{array}{c}\text { No. of } \\
\text { animals }\end{array}$ & $\begin{array}{c}\text { No. of animals } \\
\text { with positive } \\
\text { Pontamine Blue } \\
\text { response }\end{array}$ \\
\hline Saline & 4 & 5 & 0 \\
Saline & 24 & 6 & 0 \\
Oil & $0 \cdot 5$ & 9 & 0 \\
Oil & 2 & 6 & 0 \\
Oil & 4 & 6 & 4 \\
Oil & 6 & 6 & 6 \\
Oil & 8 & 6 & 6 \\
Oil & 24 & 6 & 6 \\
\hline
\end{tabular}

single and were present in all parts of the epithelial lining. These changes did not appear in the untreated horns or in the horns injected with saline. Electron microscopy confirmed the light microscope findings (P1. 1, Fig. 2). Compared to the neighbouring cells with normal ultrastructural appearance, some cells were abnormally dark and often exhibited a disorganized cytoplasm, suggesting that they were dead or dying.

Between 2 and $8 \mathrm{~h}$ after the oil injection the epithelial lining cells appeared considerably lower and broader than normal. Only occasionally were dense cells seen within the epithelial lining but they were numerous in the antimesometrial part of the lumen. There were no apparent differences between Pontamine Blue-positive and -negative areas, apart from a stromal oedema in the former. By $24 \mathrm{~h}$ after the oil injection the epithelium and the uterine lumen contained fewer condensed cells. They were primarily seen around oil droplets. Decidualization had occurred in the antimesometrial stroma.

The present results indicate that the sensitized uterine luminal epithelium is damaged within the first hour after injection of oil. No such damage occurs when oil is injected into the unsensitized uterus (Ö. Lundkvist, unpublished). Although recovery of the damaged cells might be possible, the appearance of dense cells in the lumen and the reduction in height of the remaining cells within the epithelial lining suggest that the damaged cells died and were extruded. It is therefore reasonable to assume that the dead cells observed in the mouse uterus $14 \mathrm{~h}$ after the oil injection (Hinchliffe \& El Shershaby, 1975) represent epithelial cells destroyed by the oil. Dead epithelial cells have also been seen during early implantation (Wilson \& Smith, 1970), but they are considerably fewer in number and appear later (Finn \& McLaren, 1967) than those induced by oil. Different causes of cell death are therefore possible, and we consider the one observed here as an immediate reaction to oil, unrelated to the general antimesometrial epithelial breakdown seen at later stages of decidua formation.

The instillation of oil in the rat uterus is clearly damaging to the sensitized epithelial cells, and because uterine trauma is deciduogenic (Corner \& Warren, 1919; Meyers, 1970), it cannot be excluded that oil causes decidualization by virtue of its destructive effects on the epithelium. Studies on the very early effects of other deciduogenic stimuli on the sensitized uterine epithelium are therefore in progress.

We thank the Swedish Medical Research Council (Project No 12X-70) for financial support and Miss Kerstin Rystedt for technical assistance.

\section{References}

CORNER, G.W. \& WARren, S.L. (1919) Influence of the ovaries upon the production of artificial deciduomata, confirmatory studies. Anat. Rec. 16, 168-169.
De Feo, V.J. (1967) Decidualization. In Cellular Biology of the Uterus, pp. 191-290. Ed. R. M. Wynn. North-Holland, Amsterdam. 
PLATE
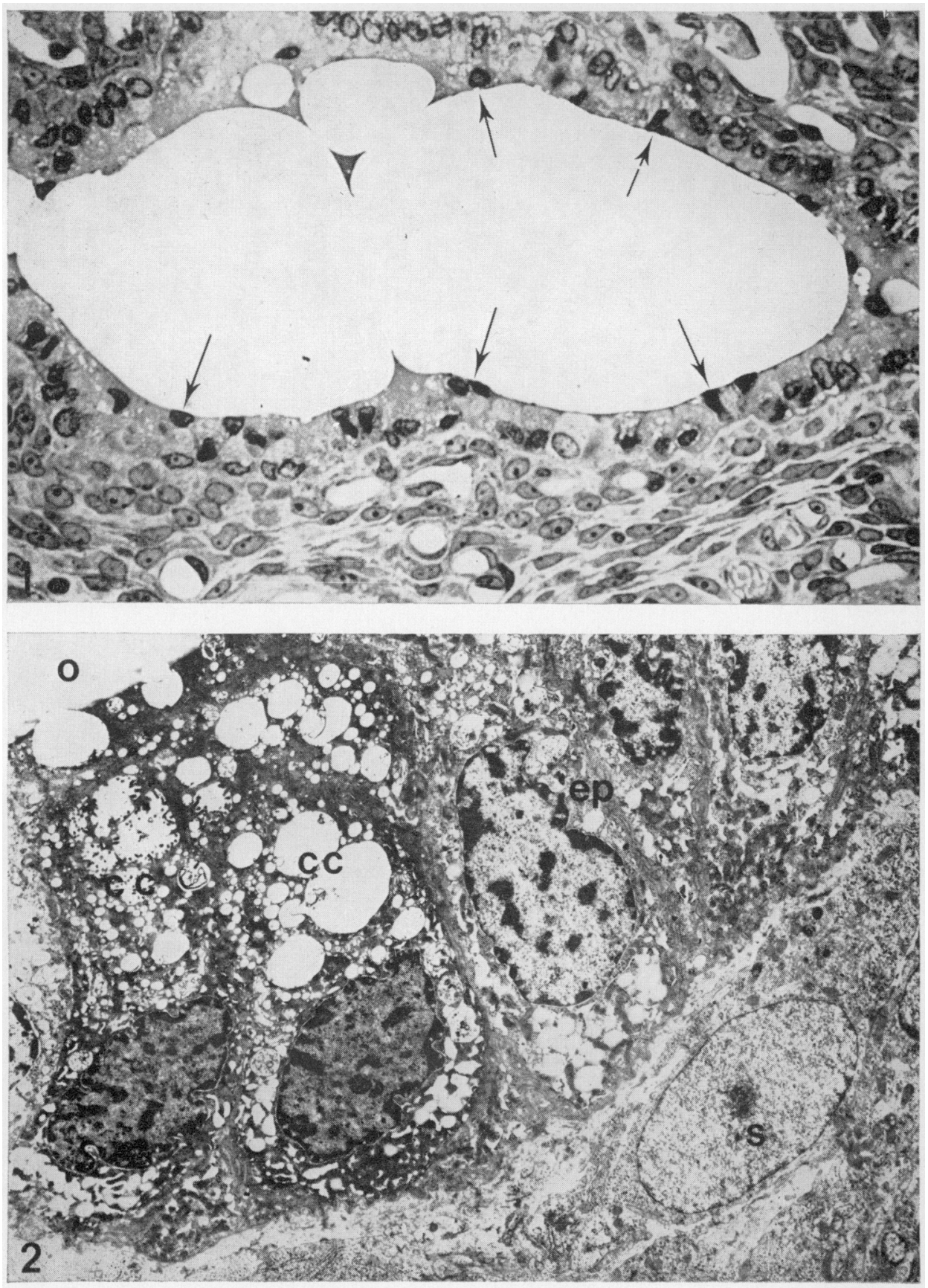

Fig. 1. Light micrograph of the uterine fumen 30 min after oil injection. The oil droplet is surrounded by the epithelial lining which contains numerous condensed cells (arrows). $\times 500$.

Fig. 2. Electron micrograph of the epithelial lining (ep) and subepithelial stroma (s) 30 min after oil injection. Note the two condensed epithelial cells (ce), adjacent to the oil droplet (o). The cutoplasm is disorganized and vacuolated. $\times 5000$. 
FInN, C.A. (1965) Oestrogen and the decidual cell reaction of implantation in mice. J. Endocr. 32, 223229.

FinN, C.A. \& Hinchurfe, J.R. (1964) Reaction of the mouse uterus during implantation and deciduoma formation as demonstrated by changes in the distribution of alkaline phosphatase. J. Reprod. Fert. 8, 331-338.

FInN, C.A. \& HinchlifFe, J.R. (1965) Histological and histochemical analysis of the formation of implantation chambers in the mouse uterus. J. Reprod. Fert. 9, 301-309.

FINN, C.A. \& KEEN, P.M. (1963) The induction of deciduomata in the rat. J. Embryol. exp. Morph. 11, 673-682.

FinN, C.A. \& Mclaren, A. (1967) A study of the early stages of implantation in mice. J. Reprod. Fert. 13, 259-267.

FInN, C.A. \& Porter, D.G. (1975) The decidual cell reaction. In The Uterus, Ch. 7, pp. 74-85. Eds C. A. Finn \& D. G. Porter. Elek Science, London.
Hetherington, C.M. (1968) The development of deciduomata induced by two non-traumatic methods in the mouse. $J$. Reprod. Fert. 17, 391-393.

HnNCHLIFFE, J.R. \& El-ShERShABY, A.M. (1975) Epithelial cell death in the oil-induced decidual reaction of the pseudopregnant mouse: an ultrastructural study. J. Reprod. Fert. 45, 463-468.

MEYERs, K.P. (1970) Implantation and deciduoma formation after administration of antiestrogen compounds. Biol. Reprod. 3, 61-66.

Miller, B.G. (1973) Metabolism of RNA and pyrimidine nucleotides in the uterus during early decidual reaction. J. Endocr. 59, 275-283.

Wilson, I.B. \& SmITH, M.S.R. (1970) Primary trophoblastic invasion at the time of nidation. In OvoImplantation. Human Gonadotrophins and Prolactin, pp. 1-8. Eds P. O. Hubinont, F. Leroy, C. Kobyn and P. Leleux. Karger, Basel.

Received 16 Mny 1977 